\title{
Religious and Cultural Relationship between Indian and Iranian Civilization: A Reading of Panchatantra and Kelileh va Demneh
}

\author{
Arnavaz Firoozian Esfahani \\ (Department of English / Gauhati University, India)
}

\begin{abstract}
In the present essay we are discussing about the civilizations of and the cultural relations between India and Iranian in the past and also at present. The first Prime Minister of India, Jawaharlal Nehru said that Iranians were among the oldest people of the world, and that the life and culture of India has been influenced a lot by Iranian civilization and culture. It is clear that both peoples, Indian and Iranian, have had close relations in the literary, culture, civilization, architectural and artistic fileds. The Rig Veda and Avesta, which are ancient Indian and Iranian Scriptures respectively, have close relation in terms of religious ideas, and books such as Panchatantra and Kelileh va Demneh are also related in numerous important ways. In this paper, it will be our endeavour to explore some of the common ground in the literary, cultural and religious fields. The specific textual focus of the paper will involve a reading of the Panchatantra and Kelileh va Demneh.
\end{abstract}

Key words: Civilization, Culture, Panchatantra, Kelileh va Demneh, Rig Veda, Avesta, origins of culture and religious.

\section{Introduction}

India has been one of the countries of high importance to Iran from times immemorial . The geography of Iran was as such that turned it to a junction giving it a special role in cultural, economic, and political relations of the world and also let it transfer the cultures from East to the West. Turkish and Tatar attackers as well as the nomadic tribes of the Middle East and the Arabs passed Iran in their attacks to India, and were of course much influenced by the Iranian culture. These attacks and movements towards India increased the cultural penetration of Iran inside India and gave India some kind of Islamic and Iranian theosophy. The Iranian thoughts were explicitly observed in t India's philosophy, language, literature, and architecture. The interaction between Iran and Indi has been as such that both have been affected by each other. The cultural, political, religious, economic, and linguistic relations between Iran and India date back to the era when these two great nations lived together inside a same border and had unit language and culture. Such relations and cultural interactions continue to exist even in the colonial era of the British ruling over India. The impact of such relations are still visible in the similarity of the beliefs, myths, theosophy, and literature of the both countries as well as the books inherited from past.

The study of the relationship between these two nations (Iran and India) is an interesting job which will definitely lead to further clarification of such relationship and increase our knowledge of the past.

A reference to the Late Prime Minster of India Jawaher Lal Nehru's words could be made here in confirmation of our discussions:

Among the many peoples and races who have come in contact with and influenced India's life and culture, the oldest and most persistent have been the Iranians. Indeed the relationship pre-cedes even the beginnings of Indo-Aryan civilization, for it was out of some common stock, that the Indo-Aryans and the ancient Iranians diverged and took their different ways. Racially con-nected, their old religions and languages also had a common background. The Vedic religion had much in common with Zoroastrianism, and Vedic Sanskrit and the old Pahlavi, the language of the Avesta, closely resemble each other. Classical Sanskrit and Persian developed separately but many of their root-words were common, as some are common to all the Aryan languages. The two languages, and even more so their art and culture, were influenced by their respective environments. Persian art appears to be intimately connected with the soil and scenery of Iran, and to that probably is due the persistence of Iran's artistic tradition. So also the Indo-Aryan artistic tradition and ideals grew out of the snow-covered mountains, rich forests, and great rivers of north India[1].

\section{The History Of The Indo-Iranian Relations}

The nations of Iran and India had been in contact in the past and even before the arrival of the Aryans to Iran and India. The historical heritage found in the archeological searches in Mohenjodar and Harppa as well as the North-west of Panjab and Estasorashtra show that in $2500 \mathrm{BC}$ there was a developed nation in the mentioned area. The historical leftovers found in India resembled those found in Iran from the Dejleh and Forat rivers showing that these two nations had close relationship and were in contact with each other. Also the 
archeological searches in 1390 (solar date) and 2000 A.D around the Silk Valley of Kashan (Iran) showed the ancient city of Kashan was the meeting point of the Iranian and Indian civilizations[2].

The Indo-Iranian tribes looked for better places for themselves and their livestock after their population increased and the need for more land was felt. So, they started migrating to the warmer lands of the West. Some groups moved to Iran, some others to Anatolia (Turkey) as well as the vast lands of India and Pakistan [3]. After these migrations the cultural and racial connections of Iran and India never stopped. The people of ancient Iran had still kept their relationships with the ancient Indian people. This was more explicitly observed in the language, myths, and customs of the Iranians and the Aryan Indians [4]. The people of Iran and India got separated as such later than other nations, and so they kept their cultural, religious, customs, and traditions commonalities.

After the Aryans moved towards Iran and India, the Indians resided in the North and their language turned to be the Sanskrit. After hundreds of years the Sanskrit became the language of a special stratum of the Indians and then the Parakrit language, which was derived from Sanskrit, was in vogue in India. The oldest holy scriptures of the Indians are the Vedas which date back to 1500 BC. The Vedas are much similar to the Avesta of the Iranians. Avesta, among the books in Sanskrit, is the most similar book to the Vedas [5].

After the migration of the Aryans to Iran, various tribes had the same language, religion, and culture since they were all derived from the same race. The Iranian Aryans, before having Zoroastrian religion, had followed Vedic as religion. So the Rig Veda is the most significant written document showing the common culture of different Aryan tribes. Sanskrit is the language of religion for the followers of Vedic religion in India, and Avesta is its counterpart for the ancient Iranians. These two languages are very similar in terms of their terminology and phonetics.

The rhythm and styles of writing poems in these two languages are so much similar that those in Avestan language can be converted to Vedic using the phonetic rules. In two texts in Avesta and Rig Veda many similar and in fact same words could be found which mean similarly and are derived from a same root in both language [2].

In the oldest parts of the Vedas mention has been made of Iran. According to Avesta, there were relationships between Iran and India before Achaemenid. In Rig Veda also mentions have been made of Iran naming it as Parshia, and later Parasikaha. The term 'Parsi' has been derived from the later word [6].

India has been mentioned many times in Avesta. In Vandidad Fargord I, there is a description of Panjab in India. In this book discussions have been made of the fifteen good places in India. The last place discussed about is the Hepta Hindu which is a land laying from East to the West of India [7].

The Sanskrit, Avestan, and the ancient Farsi languages are of a same root. The etymological study of the Vedic terms is now possible through studies of the Avestan language. Also, the translations from Sanskrit to Farsi have let many ideas to flow into the Farsi.

\section{The Indo-Iranian Mythical, Religious And Cultural Commonalities}

In addition to other commonalities, the names of the Gods and myths of Iran in Rig Veda and Avesta are very much similar. For example: Mitra in Rig Veda is in fact Misra of the Avesta; or the Yam in Rig Veda is Yam in Avesta, and Jam in Modern Farsi; Deo in Veda IS Daev in Avetsa [2].

In ancient India and Iran the Gods were of two types. The Ahoras were the source of goodness and spirituality, and the Divs of badness and materiality. After arrival of the Aryans to Sind and Iran, some changes happened in the religion of the Indian Hindus and the Iranian Aryans, meaning that the Aryans no more accepted the good Gods of the Indians and started to welcome their concept of the bad Gods. The archeological findings in Mohenjodaro and in Sind valley make reference to the times prior to the arrival of the Aryans to these areas. There the tradition of the Mother Goddess were in vogue. The Mother Goddesses sculptures found show the generality of this tradition in the mentioned area [8].

\section{Worshiping The Sun}

Worshipping the sun dates long time back in history. We can be seen sun-worship in Avesta as well as the ancient texts written in Sanskrit. In Vedic era of India the same is termed as 'Mitreh' that means friendship troth, and is one of the Gods in throne which makes alasting match with Veeneh, from whom the people ask help. Mitra is an ancient God in India it may date back to the era before the Zarostrian religion, but is in lower status as that of Oormazd in Zarostrian religion and is believed to be created by Oormazd to care of his creations [9]. Mitra is the most famous God among various Gods, and has a golden palace, and like Mitreh in India, it means the friendship troth. He leads the human beings towards proper ways and protects them from the attacks [10]. 


\section{The Holiness Of The Fire}

Respecting the fire and believing in its holiness is one of the ancient commonalities of the Indo-Iranian traditions. Its worship was supposed to be of much significance among these two nations. They used fire to get rid of the damned and impure spirits, nullifying magic, burning corpses and cleaning and sanitizing the environment [11]. In Iran there still are followers of the Zoroastrian religion who worship fire and pursue their ancient religious practices. The Zoroastrian temples still embed many ancient signs of the old history and traditions of the Zoroastrians.

\section{Sanctity Of The Cow}

The cow being regarded as a holy animal having much sanctity suggests another mythical commonality of Iran and India. According to the ancient Iranians, the cow was the first myth ever in creation of the world, in white color and bright as moon. In Zoroastrian religion it is stated that the bull created by Ahora Mazda is killed by the demons and its semen travels to the moons and, after being purified, it turns to many different animals. Also, many vegetables grow as the result of some of that semen being poured on the earth [10]. Cow in Iranian mythology represents the moon, and clouds represent flock, of the sheep.

In Indian mythology Indra is one of the most ancient and powerful Gods, and is the source of raining, snowing, and lightening.. Rig Veda speaks of a cow which gives life to everything and mentions that the cow makes intercourse with all the Gods and gives birth to whole the world. The life of the Gods is granted to them by the female cow [8]. In Iran as well the cow is supposed to be a holy animal for it helps much in agricultural activities. It represents Mitra. In Iranian mythology cow is the symbol of rain, cloud, and tornado. Thebull is the symbol of prosperity, affluence, and goodness [12].

\section{The Iranian Festivals And Traditions Of India}

The Nowroz festival entered along with Farsi language into the Indian subcontinent. It is the New Year festival of the Iranians which remains to be the most significant of all the festivals for them. The Nowroz, the Mehregan, and the Sadeh festivals have been prevalent in Iran from the time Ghaznavids (975-1877 A.D). These festivals are of course Indo-Iranian that have changed over the history. The Ghaznavids held these festivals in the best form possible and the Farsi-speaking poets sang many poems in praise of spring and these festivals which were in celebrated the beginning of the spring.

Amir Khosroo Dehlavi the poet of the seventh century was the greatest Indian Farsi-speaking poet who wrote more than a thousand verses. In all his poems the Iranian culture and civilization is explicitly observed. In his book 'Matlaa- al- Sa'adein' he has a long masnavi where he speaks about the Nowroz festival and that how it was celebrated, and states that the same tradition is of great importance among the Indian nation and that it even assumes more importance than the Indian local festivals [13].

In the Timurid era (1370-1506 A.D) also the Iranian festivals were prevalent. The 'water-splashing' festival was held all over Iran. The most significant Nowroz festival in the Timurid era was held in Delhi.

In Akbar Nameh, Abolfazl Eelami states: "Because of the importance and the value of the festivals which were held for thousands of years, and the happiness, prosperity, bliss, and the justice they brought to the country, Akbar Shah ordered for re-holding of the same, which were abandoned for a while, in its best possible forms in India" [14].

In Akbar Shah Gorkani's Kingdom (1542-1605 A.D) the Iranian festivals came in vogue again by the King's order in 922 Hijri (1584 A.D) due to his interest to the solar date. In those days the Nowroz festival lasted for nineteen days, from Farvardin the first to Farvardin the nineteeth. In those days they decorated the walls of the government building with the most expensive, colorful, and golden cloths and curtains. Inside the palace they decorated the throne with gold, ruby, and the most expensive gems. At the nights they lit colored lanterns. The King came to his palace twice a day and spoke to the people present there. They decorated the public bazaars and the people came from everywhere to watch such decorations [14].

After Akbar Shah, his son Jahangir inherited the throne (1569-1627). He reigned for 22 years. In his Kingdom he used to note the yearly incidents of his Kingdom in Farsi, which later on was known as Tozak-e-Jahangiri. He has wrote about 17 years of his Kingdom using titles such as: the first Nowroz, the seconnd Nowroz... and the seventeenth Nowroz [14].

Shah Jahan (1592-1666) the son of Jahangir also held the Nowroz festivals in its best possible form. He sat on 'Takht-e-Tavoos' (The throne of the peacock), which cost 10 million Rupees, in the Nowroz festivals.

One of the traditions in Nowroz was that the people splashed water and rosewater on each other. This tradition is still alive among the Pakistani Shias. There they gather together sometime prior to the new year's starting time around the Haft Sin and put a bowl full of rosewater and after the new year comes they splash it towards each other. 


\section{Architecture}

The signs and traces of the Iranian culture and civilization in Indian subcontinent are evident. In the archeological searches of Patali Putra, the capital city of the Maurya Empire, a saloon full of the stone columns dating back to 300 B.C were found which resembled the columns s of the Takht-e-Jamshid of Iran and were similar in style to Achaemenid architecture of Iran. Also some inscriptions, which are now in the Seranat museum, along with the columns found dating back to Ashoka's era (the famous King of the Morani Kingdom 232-273 A.D) who was the successor of Chandra Gupta, prove similarity to those inscriptions and columns found in Takht-e-Jamshid of Iran. The Achaemenid era is they past, but the ancient Iranian architectural and sculptural traces were still left in India. It is worthwhile knowing that the tradition of engraving and writing on the stones and the caves was firstly done in Iran for there is no trace of the same in India prior to Ashoka era. It was firstly in the Median territory, and then in Fars territory around 1000 A.D when the Aryans started digging caves and decorating them as well as placing columns inside the caves. Ashoka later on imitated this art in the mountains of the Bihar state. Darius I had got the famous Biston inscription prepared in 518 A.D, while Ashoka imitated the same only around 250 A.D and also imposed some changes according the Indian style. Sculptures of hanging bells were changed into Inverted Lotus which is the sign of something else.

The crafts of Ashoka in India were immensely inspired by the architecture of Persepolis. The GrecoBuddhist crafts of the North-west India and those found in Afghanistan are not empty from such influences [5].

The Taj Mahal of Agra, which is supposed to be one of the architectural wonders of the world, was constructed by an Iranian architect named Isa Isfahani. It is a great work of art which Rene Gerosseh the French scholar calls "the soul of Iran represented in Indian body". The other very significant constructions is "Takht-eTavoos' of Shah Jahan, which itself is one of the great works of art in the world. It was made by Saeid Shaer Gilani Zargar Bashi. It is in fact was destroyed by Nader Shah in his attack on India. The mentioned places are but two examples of the Iranian architecture in India [15].

After all there is no doubt that the Indian Kings imitated the architecture of the Mauryan era, and then the Achaemenid architecture.

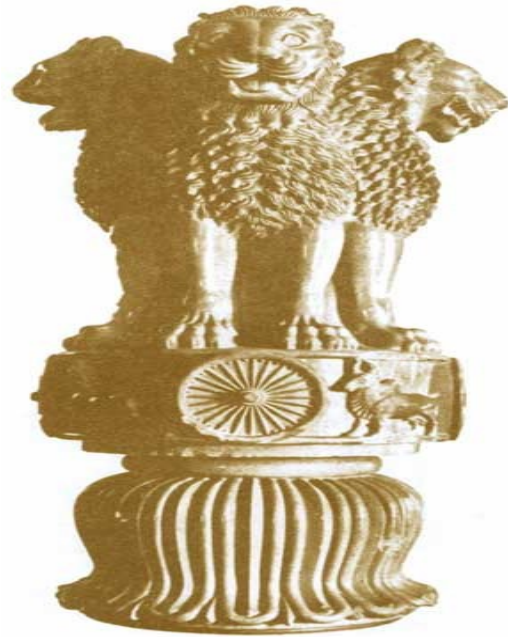

The sculpture of the Ashoka pillar which includes four lions sitting back to back on a bell-shaped column, it is in fact an imitation of the columns of Takht-e-Jamshid which were built in 300 A.D, and is now in the Banaras Museum

\section{Indo-Iranian Cultural Similarities From The Perspective Of Kelileh And Demneh}

The Iranian Kings of the Sassanid Era (226-651 A.D) had friendly relationships with the Indian kings including those of the Gupta Kingdom (230-530 A.D). In the era of Gupta Kingdom the literary and artistic relations of Iran and India was at the highest. In the same era there also were strong political, cultural and trading relations between these two great nations. As stated by Firdausi in his Shahnameh, Bahram Goor, one of the Sassanid Kings, asked from Shengel the King of India to choose a thousand female singers and send them to Iran in order to teach the Indian music in Iran and, and the Indian King did as requested.

From political perspectives it needs mentioning that in the above mentioned era the power and influence of Iran in the Northwestern lands of India expanded and the rulers of these areas regarded Artaxerxes as their King. Mani, the Iranian Prophet, traveled to India because He has not being paid due attention in Iran during the era of the Shapoor I of the Sassanid Kingdom (241-273 A.D) and the attracted followers in India.

In the era of the Kingdom of Khosrow I Anoshiravan (531-579) the relations between Iran and India expanded more than ever and many people followed between these countries. The Indo-Iranian scientists and 
scholars traveled to each other's countries and learned about the other's knowledge. The Islamic historians have written that the Sassanid King attacked India. Balami writes that: "Anoshiravan attacked India, and the Indian king surrendered to Anoshiravan and gave back the Jordan to Iran" [16].

In this era Kelileh and Demneh, which originally was named Panchatantara and written in Sanskrit, was translated into Pahlavi language by Borzoyeh Tabib. When Anoshiravan became the King, he ordered for Kelileh and Demneh to be brought to Iran and then got it translated from Sanskrit into Pahlavi language. Ibn alMuqaffa translated the same book from Pahlavi into Arabic in the second century, and Nasr Allah Monshi translated it into Farsi [17] .

These differences could be studied from cultural, religious and social perspectives as well. For example, a story has been written in different issues having differences in:

1 - hero of the story

2- theme of the story

3- imaginations of the heroes of the stories

4- Ending and conclusion of the story.

\begin{tabular}{|l|l|}
\hline $\begin{array}{l}\text { KELILEH AND DEMNEH } \\
\text { (Monshi,1997,p:263) }\end{array}$ & $\begin{array}{l}\text { PANCHATANTRA } \\
\text { (Indoshkher,1962,p:183-186) }\end{array}$ \\
\hline The Pious & Brahmin (Overwhlmed) \\
\hline $\begin{array}{l}\text { The urn of honey and the oil which was left from the food } \\
\text { offered by the merchant }\end{array}$ & The urn of the flour \\
\hline $\begin{array}{l}\text { Selling this good and buying a goat and then turning that goat to } \\
\text { a herd of goats, then buying a house and marrying with Khan's } \\
\text { daughter }\end{array}$ & $\begin{array}{l}\text { Selling goods and buying goat, cow, and buffalo, and then } \\
\text { buying a house and marrying with Brahmins' daughter }\end{array}$ \\
\hline $\begin{array}{l}\text { Having a son and choosing a good name for him, the son not } \\
\text { being in control and punishing him by a stick, and the oil being } \\
\text { spilled from the urn }\end{array}$ & $\begin{array}{l}\text { Having a child and the son showing his ability in walking } \\
\text { and running toward Brahmin who is reading a book behind } \\
\text { the stable and the mother not taking good care of the child, } \\
\text { the Brahmin getting angry and punishing, the flour being } \\
\text { poured }\end{array}$ \\
\hline
\end{tabular}

By comparing parts of the story in two languages we conclude that the base for allegory is same in all: a pious overwhelmed by his imaginations about the future is suddenly knocked leading to all his thoughts being torn up. Such similarity shows the affinity of the cultures and customs between the Indian and Iranian nations. What is clear here is that the story is derived from the social, religious conditions as well as world-views of the Indian and Iranian societies. The hero of the story in Persian version is a pious man and in Indian version is Brahmin, clarifying the educational and intellectual environment of the both societies .

In Indian version the urn is filled out by flour being begged, and in Iranian version the same is filled out by the honey and oil being gifted by a merchant or an eminent person of the city, and in all versions having a herd, building a house and marrying with a girl from a reputed family is emphasized. In the fourth section of the story one of the basic characteristics of the Indian and Iranian world-views could be seen:

In Iranian story the education of the child, choosing a good name for him, and finally punishing him if he does now listen to his parent are clearly recommended. But in Indian story punishment of the wife is stated. This difference shows that the issue is either from Panchatantara which has its roots in Pahlavi, or that it is the change imposed by Nasr Allah Monshi in the text. The Sanskrit version of the story is not available, and the direct translations from Pahlavi do not include this story, so that talking strictly about this issue does not hold water. But having the good acquaintance of the Iranian society of Sasani era, and noting the Zoroastrian religion enables us to conclude that choosing a proper name for the child, and trying to educate him well and also punish him when not in control were the intention of the same story and writings, "if a child does not make proper attempts in his education and, resultantly, ruins his teacher's reputation, he is liable for punishment" [18] .

The other point is the difference seen in opening of the story. In the Iranian versions the urn is filled out by the honey or oil being gifted by a merchant, and in Indian version the same is filled out by the flour being begged. This may be due to the Iranian culture in which beggary is not good for a pious man, but receiving the gifts was part of the prevalent custom and tradition of the then society. These differences mark the cultural and religious similarities and differences of the Indian and Iranian nations.

\section{Discussion And Conclusion}

Among different nations, Iran and India have had deep relations with each other along the history in different fields. Both the nations have had outstanding impacts and enjoyed on each other's literary, cultural, religious, and architectural codes from the far history up until nowadays. The Farsi-speakers had significant role in such a trend and many books were translated into Farsi in the mentioned era. Many poets, theosophists, and scientists of Iran went to India and transferred the knowledge to their country. Many theosophical, historical, religious, and philosophical books as well as many collections of Farsi poems and dictionaries were collected over the centuries, which are now supposed to be of the greatest heritage of the world. A great portion of the 
Indian ancient books are in Farsi, and many hand-written books could be found in Indian museums and libraries. It is about two centuries that Farsi is no more the prevalent language of the Indian subcontinent. The colonization being imposed by Britain sidelined Farsi language and let the English language to come in vogue in India. Thought there is no hope for Farsi to come in vogue again in India like the past times, but it is still hoped that the Farsi language be revitalized in India like what is seen in Pakistan and Bangladesh. This is job of the authorities and thinkers of these two countries to obviate the obstacles and try to re-build the cultural relationships, and compensate the lost opportunities.

\section{Reference}

[1] Nehru, Jawaharlal, (1946)The discovery of India, Signet press publication, New Delhi.

[2] Jalali Naiieni, MOhamad Reza,(1985) Hend dar yek negah, Sokhan publication, Tehran.

[3] Farahvasi,Bahram,(1991) Iranvich, Tehran university publication, Tehran

[4] Amozegar, Zhaleh,(1995) Resale dar tarikh Iran, Sorosh publication,Tehran.

[5] Nehru, Jawaharlal, (1982) Kashfe hend, (Translated by Mahmod Tafzili ), Amir Kabir publication ,Tehran

[6] Hekmat, Ali Asghar, (1988) Sarzamin Hend ,Tehran university publication ,Tehran.

[7] Razi, Hashem, (1997)Vandidad, Fekre Roz publication, Tehran.

[8] Dadvar, Ab Alghasem ,Mansori ,Elham (1999), Baresi tatbighi naghshe Gav dar asatire va honare Iran va hend,Majale motaleat Irani - 14, Tehran.

[9] Bahar, Mehrdad,(1996) Adyan Asiai , Cheshmeh publication ,Tehran

[10] Curtis, Vesta Sarkhosh, (1972) Osturehaye Iran, (Translate by Mokhber Abas), Markaz Publication, Tehran.

[11] Widengren, Geo (1998) Dinhaye Irani, (Edited by Farhang, Manuchehr), Agahan Ide Publication, Tehran.

[12] Gertrude Jobes,( 1991) Sambolha, Translate by Baghapur Mohamad Reza, Motarjem publication,Tehran..

[13] Dehlavi, Amir Khosro, (1976) Garn Al Sadain, Edited by Dani Ahmad Hasan, Islam Abad, Pakistan.

[14] Razi, Hashem (2006) Jashne ab, Behjat publication, Tehran.

[15] Mashayekh Feriydani, Mohammad Hossin, (1986 ) Payvastegi Ordo va Farsi Dari, Markaz Nashr Daneshgahi , Tehran .

[16] Balami, Abo Ali Mohammad, (1974) Tarikh Balami (Edit by Bhar, Mohammad Taghi , Gonabadi ,Mohammad Parvin), Zavar publication, Tehran.

[17] Monshi, Nasr Allah, ( 1997) Kelileh va Demneh,( Edit by Minovi Mojtaba ) Amir Kbair publication, Tehran.

[18] Rashed, Mohammad Tghi (1987), Gozide haye Zadsprem, Moaseseh Motaleat farhangi publication, Tehran . 